\title{
Sprawozdanie ze stanu realizacji inwestycji budowy nowej siedziby Archiwum Narodowego w Krakowie
}

Przygotowania do budowy nowej siedziby Archiwum Narodowego w Krakowie rozpoczęły się od pozyskania w 2013 r. odpowiedniej nieruchomości, nadającej się na lokalizację dużego budynku archiwalnego. Decyzją Prezesa Agencji Mienia Wojskowego z dnia 15.07.2013 r. przekazano Archiwum nieodpłatnie w trwały zarząd parcelę oznaczoną nr 219/15 obręb 8 Śródmieście, z przeznaczeniem na wybudowanie nowej siedziby dla Archiwum. Nieruchomość ta przylega od południa do muru Cmentarza Rakowickiego i znajduje się w środku obszernego kwartału terenów powojskowych położonych między ul. Rakowicką a ul. Wita Stwosza. Obecnie teren ten jest miejscem intensywnych prac budowlanych, które zmienią zupełnie jego oblicze i przekształcą w atrakcyjną dzielnicę położoną w najbliższym sąsiedztwie Dworca Głównego w Krakowie. Obok Archiwum swoją siedzibę znajdzie tutaj Muzeum Historii Fotografii im. Walerego Rzewuskiego w Krakowie. Funkcjonuje natomiast już od dawna Muzeum Armii Krajowej im. gen. Emila Fieldorfa „Nila”.

Celem inwestycji jest wybudowanie gmachu, który zdolny byłby pomieścić w jednym miejscu nie tylko całość obecnego zasobu Archiwum (ok. $25 \mathrm{~km}$ akt przechowywanych w aż pięciu lokalizacjach w Krakowie oraz w zamiejscowej ekspozyturze w Spytkowicach koło Zatoru), ale także kilkanaście km materiałów archiwalnych zaplanowanych do przejęcia w najbliższych latach od innych organów administracji publicznej. Nowa siedziba powinna zapewnić przejmowanie bez opóźnień współcześnie wytwarzanych materiałów archiwalnych w perspektywie przynajmniej 25 lat, po upływie których ilość przejmowanych akt winna się systematycznie zmniejszać ze względu na upowszechnianie dokumentów elektronicznych w obiegu prawnym. Oprócz odpowiedniej pojemności priorytetem jest także zapewnienie bezcennym zbiorom właściwych warunków klimatycznych i bezpieczeństwa, przy akceptowalnym poziomie nakładów finansowych na ten cel, co w starych budynkach, adaptowanych zaledwie na potrzeby archiwalne, jest niemożliwe ze względów technicznych lub finansowych.

Powyższe wymagania uwzględniono przy projektowaniu nowego budynku. Jego powierzchnia zabudowy wyniesie ok. $2400 \mathrm{~m}^{2}$. Zajmie środek działki o powierzchni prawie 1 ha, co umożliwi bezkolizyjną w przyszłości ewentualną rozbudowę magazynów. Wolne przestrzenie na parceli zostaną do tego czasu wykorzystane na parkingi i powierzchnię czynną biologicznie. Zachowano także istniejące dwa niewielkie budynki historyczne (elementy XIX-wiecznej twierdzy Kraków), które po odbudowaniu przeznaczone będą na stację trafo oraz śmietnik. Powierzchnia użytkowa głównego budynku wyniesie aż 14 059,33 $\mathrm{m}^{2}$, a kubatura - $64719 \mathrm{~m}^{3}$. Składać się będzie z dwóch segmentów połączonych przewiązką. Segment magazynowy o wysokości $24 \mathrm{~m}$ liczyć będzie 8 kondygnacji 
(w tym 1 podziemna), segment biurowy o wysokości $20 \mathrm{~m}-5$ kondygnacji (w tym jedna podziemna). W części magazynowej pomieścić będzie można ok. $80 \mathrm{~km}$ akt. Pozbawiona okien i zaprojektowana przy zachowaniu rygorystycznych współczynników przenikania ciepła przez ściany pozwoli na zapewnienie stałego klimatu przy jak najmniejszych nakładach na ten cel. Zastosowanie odpowiednich materiałów budowlanych do wzniesienia ścian zewnętrznych, systemów wentylacji i utrzymywania ciepła lub chłodu w budynku (tzw. budynek pasywny), systemów osuszania powietrza, systemów przeciwpożarowych bez stałej obecności wody w instalacjach w magazynach archiwalnych oraz wymagań co do wytrzymałości stropów pozwoli na zapewnienie aktom właściwego mikroklimatu i bezpieczeństwa w stopniu dotychczas nieosiagalnym. Cały budynek posadowiony będzie na ponad 100 tzw. palach aktywnych (z kolumnami geotermalnymi) pobierających ciepło $\mathrm{z}$ gruntu. W połączeniu z kilkunastoma głębinowymi sondami geotermalnymi oraz pompami ciepła dostarczą one wystarczającą ilość energii cieplnej dla budynku bez korzystania z zewnętrznego ogrzewania. Pozwoli to na znaczne obniżenie kluczowego kosztu zapewnienia właściwych warunków klimatycznych do przechowywania materiałów archiwalnych.

Segment biurowy, w którym warunki klimatyczne będą odpowiednie do stałego przebywania pracowników, poza pomieszczeniami biurowymi zawierać będzie m.in.: czytelnię do pracy z aktami na ok. 100 stanowisk, nowoczesną salę konferencyjną zdolną pomieścić do 150 osób, duże (ok. 200 m²) pracownie konserwacji materiałów archiwalnych, pracownię introligatorską, digitalizacyjną oraz olbrzymie repozytorium cyfrowe, mogące pełnić rolę zapasowego (w stosunku do Narodowego Archiwum Cyfrowego) miejsca przechowywania reprodukcji cyfrowych materiałów archiwalnych z całej Polski. Segment posiadał będzie dodatkową, przezroczystą fasadę. Warstwa powietrza między nimi pomagać będzie w utrzymaniu odpowiedniej temperatury w środku budynku, obniżając tym samym koszty działania systemu klimatyzacji. Na dachu całego budynku umieszczone zostaną z kolei panele fotowoltaiczne, dostarczające istotną część energii elektrycznej dla obiektu.

Przewidywany czas wykonania robót budowlanych to okres 2017-2019. W $2020 \mathrm{r}$. Archiwum mogłoby zwolnić dotychczas zajmowane siedziby, w tym zamek w Spytkowicach i przewieźć cały zasób do nowego budynku. Pełny koszt inwestycji, łącznie z przeprowadzką, szacowany jest na ok. $100 \mathrm{mln}$ zł. Źródłem wszystkich środków jest budżet państwa w części dysponowanej przez Ministerstwo Kultury i Dziedzictwa Narodowego.

Przez okres 2013-2016 trwały prace projektowe oraz czynności administracyjne wymagane przez przepisy prawa do rozpoczęcia budowy. Na długi czas przygotowań wpływ miała przede wszystkim skala inwestycji implikująca nie tylko duży nakład pracy do stworzenia dokumentacji projektowej, ale również wysoki rygoryzm procedur udzielania zamówień publicznych, przewidziany dla wydatków tego rzędu. Ze względu na lokalizację budowy istniała ponadto konieczność uzgadniania dokumentacji projektowej oraz wycinki drzew z placu budowy z Małopolskim Wojewódzkim Konserwatorem Zabytków (MWKZ).

Archiwum uzyskało 3 decyzje o ustaleniu lokalizacji inwestycji celu publicznego, pozwalające na prowadzenie inwestycji w zakresie budowy nowego budynku (decyzja z 09.12.2013 r.) oraz budowy sieci kanalizacji (decyzja z 09.12.2015 r.) i wodociagowej (decyzja z 28.04.2016 r.) na odcinku między działką Archiwum a ul. Rakowicką. Pozwo- 
lenia na budowę noszą daty 08.06.2016 r. i 08.11.2016 r. (sieć wod.-kan.). Pozwolenia na prowadzenie robót budowlanych na terenie wpisanym do rejestru zabytków wydane zostały z kolei przez MWKZ w dniach 11.12.2015 r. i 27.07.2016 r. Podpisano także odpowiednie umowy z zakładami energetycznym (04.12.2015 r.) i wodociagowym (06.10.2016 r.) określające sposób dostarczania wody i energii elektrycznej do budynku Archiwum oraz odprowadzania ścieków, własność projektowanych sieci oraz finansowanie ich budowy. Ze współwłaścicielami terenu, przez który przebiega droga dojazdowa do działki Archiwum zawarto w dniu 25.10.2016 r. umowę w sprawie współfinansowania przebudowy drogi i położenia pod nią instalacji technicznych.

Koncepcję programowo-przestrzenną nowej siedziby Archiwum wykonało 20.12.2013 r. ID Biuro Projektów Sp. z o.o. Program funkcjonalno-użytkowy nowej siedziby opracowany został przez firmę „Stanisław Pochwała DELTA” w grudniu 2013 r. Po zaopiniowaniu programu przez Naczelną Dyrekcję Archiwów Państwowych, w październiku 2014 r. został ogłoszony konkurs na koncepcję architektoniczno-użytkową nowej siedziby Archiwum, którego uroczyste rozstrzygnięcie miało miejsce 20 kwietnia 2015 r. Sąd Konkursowy na czele z prof. dr. hab. inż. arch. Andrzejem Wyżykowskim wyłonił laureatów spośród 15 zgłoszonych prac. Pierwsze miejsce przyznano pracy zespołu Q Arch Sp. z o.o. z Krakowa. Autorami drugiej nagrodzonej koncepcji zostali architekci z krakowskiej Pracowni Konserwacji Zabytków Arkona Sp. z o.o. Trzecie miejsce przyznano pracy WXCA Sp. z o.o. z Warszawy. Wyróżnienie Sąd Konkursowy przyznał koncepcji architektonicznej hiszpańskiej firmy Guillermo Vázquez Consuegra Arquitecto SLP z Sewilli. Spośród nagrodzonych trzech prac w dalszym postępowaniu o udzielenie zamówienia publicznego prowadzonego w trybie negocjacji bez ogłoszenia wyłoniona została firma Pracownie Konserwacji Zabytków „Arkona” Sp. z o.o., która następnie otrzymała zlecenie na wykonanie dokumentacji projektowej nowego obiektu. Umowę na sporządzenie projektu oraz późniejsze prowadzenie nadzoru autorskiego podczas budowy podpisano 15.07.2015 r. W wyniku realizacji umowy w grudniu 2015 r. przedstawiony został Archiwum gotowy projekt budowlany, natomiast ostateczne wersje projektu wykonawczego, specyfikacji technicznych, przedmiar robót, kosztorysu inwestorskiego oraz harmonogramu robót - 11.08.2016 r. po uzyskaniu zatwierdzenia projektu budowlanego przez Wydział Architektury i Urbanistyki Urzędu Miasta Krakowa.

Obsługę prawną konkursu architektonicznego oraz udzielenia zamówienia publicznego na wykonanie dokumentacji projektowej prowadziła Grupa Doradcza Sienna Sp. z o.o., natomiast od 12.05.2016 r. obsługę prawną kolejnych przetargów i całej inwestycji zlecono Kancelarii Radców Prawnych „Ćwik i Partnerzy” Sp. p., z którą podpisano stosowną umowę. Z kolei, w wyniku przetargu nieograniczonego na świadczenie usług Inwestora Zastępczego, w dniu 10.01.2017 r. podpisano umowę z ECM Group S.A. na obsługę inwestorską budowy. Podmiot ten prowadził będzie w pełnym zakresie nadzór budowlany nad inwestycją.

Pierwszymi pracami na terenie budowy było przeprowadzenie w listopadzie $2016 \mathrm{r}$. wycinki i usunięcia drzew i krzewów z działki. W zamian za wycinkę, zgodnie z decyzją MWKZ z dnia 15.09.2016 r., wykonano nasadzenia zastępcze 247 drzew na terenie Lasu Wolskiego i ogrodu zoologicznego w Krakowie. Obecnie trwa postępowanie o udzielenie zamówienia publicznego na generalne wykonawstwo robót budowlanych. Wybór zwycięz- 
cy przetargu spodziewany jest w marcu 2017 r., co oznacza początek właściwych prac na wiosnę $2017 \mathrm{r}$.

Budowa nowej siedziby i przeprowadzka do niej będą najważniejszym zadaniem Archiwum Narodowego w Krakowie na najbliższe lata. Nowy obiekt będzie zaś najnowocześniejszym i największym budynkiem archiwalnym w Polsce - przynajmniej do czasu wybudowania Archiwum Rzeczypospolitej w Warszawie, którego stworzenie planowane jest na III dekadę XXI w.

Pawet Zabczyński Archiwum Narodowe w Krakowie 